\title{
Naturalistic Observation in the Hispanic World and its Contribution to the Development of Comparative Psychology
}

\author{
J. Javier Campos Bueno ${ }^{1}$, Pedro Montoya ${ }^{2}$ y Niels Birbaumer ${ }^{3}$ \\ ${ }^{1}$ Universidad Complutense (España) \\ ${ }^{2}$ Universitat de les Illes Balears (España) \\ ${ }^{3}$ Universität Tübingen (Alemania)
}

\begin{abstract}
The observation and descriptions of animal's behavior and emotions from the New World began shortly after the arrival of Spaniards in America. The discovery of the Indian natives and completely unknown species in Europe sparked a great interest in pioneers like Álvarez Chanca, Fernández de Oviedo, Cieza de León, Sahagún, Francisco Hernández, Acosta, Cobo or much later by Azara. In our opinion, these studies provided the basis for the study of animal behavior and emotions in the New and the Old World and allowed a new understanding of the Natural History and the relationship between structure and function. It is likely that these findings were crucial for the work of Charles Darwin three Centuries later. Moreover, it is suggested that the future development of Comparative Psychology based on Darwin and Romanes work, based its roots in the work and observations of these early pioneers.
\end{abstract}

Keywords: Darwin's anniversary, behavioral observation, emotion, natural history, comparative psychology, pain empathy.

La observación y la descripción del comportamiento y de las emociones de los animales del Nuevo Mundo se inició poco después de la llegada de los españoles en América. No solo causó asombro el encuentro con los indios nativos sino también la existencia de especies completamente desconocidas en Europa. Este descubrimiento despertó un gran interés en pioneros como Álvarez Chanca, Fernández de Oviedo, Cieza de León, Sahagún, Francisco Hernández, Acosta, Cobo o mucho más tarde Azara. En nuestra opinión, estos estudios sirvieron de base para el estudio del comportamiento animal y las emociones tanto en el Viejo Mundo como en el Nuevo y permitió una nueva comprensión de la Historia Natural y de la relación entre estructura y función. Es probable que estos hallazgos iniciales fueran cruciales en los posteriores estudios de Charles Darwin, tres siglos más tarde. Por otra parte, se sugiere que el desarrollo de la Psicología Comparada que se produce a partir de la segunda mitad del siglo XIX, a partir de la obra de Darwin y Romanes asientan sus en sus raíces en el trabajo y las observaciones de estos pioneros.

Palabras clave: Aniversario de Darwin, observación conductual, emoción, historia natural, psicolog ía comparada, empatía con el dolor.

Agradecimientos: Ministerio de Ciencia e Innovación y Fondos FEDER (SEJ2007-62312). Grupo de Historia de la Neurología de la Sociedad Española de Neurología. Grupo Santander, Programa de Profesores Visitantes Distinguidos en la U. Complutense. Una versión abreviada de este trabajo fue presentada en el Congreso de la Sociedad Española de Historia de la Psicología y puede consultarse en Campos, Montoya y Birbaumer, (2009).

Correspondence concerning this article should be addressed to J. Javier Campos Bueno. Facultad de Psicología. Universidad Complutense. Somosaguas, Madrid 28223. (Spain). Phone: +34-913943035 . Fax: +34-913943189. E-mail: jjcampos@psi.ucm.es 
The year 2009 marks the 200th anniversary of Darwin's birth and the 150th anniversary of the publication of his key work The Origin of Species. Since then, no scientist has matched the impact made by these discoveries, not only to science, but fields as varied as religion, philosophy, politics or art. To find a discovery with such scientific and social impact, we must rewind three centuries to a time before the Darwinian Theory when America was discovered. Indeed, in light of Renaissance ideas, the discovery of America proposed an extraordinary challenge of integrating all the ancient knowledge with that produced from contact with the American people and land. In continual contact with the great American cultures, the Spanish spread these findings throughout the Old World for several centuries. Additionally, the works of these chroniclers are now used as a reference for the study of American history (Keniston, 1920). Rey Pastor has suggested what may have desagree from the scientific significance of such Spanish explorations of the New World. The scientific renaissance is the result of an awakening of conscience, something which was occurring in many European regions at the time. This rebelled against the unfounded respect for the classic authors, but would not have happened from an intellectual position without the worth of humanity, not for the reckless courage of those men capable of risking their lives to ensure the veracity of the horrific descriptions of the dark seas closed from human beings. The courage of the Spanish and Portuguese explorers during the fifteenth century permitted the revelation of the inconsistency of Aristotelian dogmas about the impenetrability of the Torrid Zone and the falsity of Ptolemy's southernmost continent. Against the wise opinion of the philosophers, these explorers "not only made possible the Hispanic epic, but also the advent of modern science, free from prejudices of authority, which they succeeded in overthrowing. The experience and firsthand look at the facts, is since then the supreme criterion of truth, which dethroned the criterion of authority. "(Rey Pastor, 1951, pp. 23-24).

The comments of the chroniclers of the Indies completed our knowledge, although only to the extent of the precarious state of science at the time. They were able to show that winds and ocean currents, volcanoes and earthquakes were related and so revealed to us the physical harmony. Moreover, the gradation of plant and animal species, or the similarities between distant indigenous languages showed us the biological and functional unity of a global world. Not surprisingly, those descriptions of Gomara, Oviedo, Acosta or Hernandez were favorably commented by the appreciative Humboldt, in the words of Rey Pastor (1951, pp. 36-37). "It's a mistake to believe," says Humboldt, "that the Europeans were guided only by the love of money or by religious fanaticism. Dangers always elevate the poetry of life; and, as well, the vigorous era, whose influence on the development of the idea of the world we now find ourselves, provided to all the actions and impressions of nature to give rise to the charm of far off travels that starts to wear off in our Scholar's era, amid countless facilities that gave access to all regions, that is: the charm of novelty and surprise". (Humboldt A., 1855, pp. 328).

The discoverers face the adventure of discovery with a medieval preconception. Animals like the basilisk, griffins, ants as dogs, the phoenix, dragons, amazons and mermaids, men Cyclops and others with four eyes or with dogs' heads or horse hooves, all form a mythical zoology rooted in the credulous faith of the conquerors, predisposed to finding all sorts of fabulous creatures. Many of the animals are like that of the dragon, expressed in the literary terms of Borges (1957) with, "we ignore its meaning, as we ignore the meaning of universe, but there is something about its image that fits with the imagination of men", in other words, these monsters are necessary for those people with such limited and partial knowledge.

What then is the state of science? "Aristotelian science -continues Rey Pastor- was essentially qualitative, owing to merited substances and moral qualities: affinities and antipathies that explained its behavior. More modest in its claims, the Renaissance science is limited to discovering the how and not the why of the phenomena, and that behavior of nature reduces the science to precise quantitative relations, verifiable, numerical (pp. 38-39).

This clash of cultures and attitudes will lead to the ongoing development of new knowledge and social ideas that eventually culminate in the European and American revolutions, and in the expansion of scientific knowledge during the nineteenth century, in which Darwin's theory of evolution plays a prominent role.

The seed of evolutionary ideas had already planted in Spanish's field work on American soil (Bandres, Campos y Llavona, 1989). The discovery of completely unknown animals in Europe sparked a great interest for writers to describe these species and their behavior. The early descriptions included more detailed observations, some of which were made with great resources and driving force from the Spanish Crown and Church. There were many authors who contributed to the study and the dissemination of the results was rife in Europe. Here some of the most prominent results will be reviewed. In their descriptions of the unknown species in the Old World, these Spanish put to the table the question of the origin of species. European naturalists were forced to reconcile the new facts with the versions derived from biblical texts. This can be seen in the Natural and Moral History of the Indies (1590/1792), by the Jesuit Jose de Acosta, which at the time was edited 32 times in six languages (see Lopez-Pinero, 1982, p.27). These studies and observations were strongly driven with the passion of the conquest by these Spanish pioneers, who laid down the foundations for further study of the relationship between structure and function, an issue that will be crucial in Darwin's work. The future development of comparative psychology driven by the publication of Romanes' work, took early inspiration from the work and observations of those first explorers. 


\section{A New World}

The first news we have in Europe about the American animals was provided by Diego Alvarez Chanca ( $i-c .1515)$, a Spanish Navy doctor. This Spaniard had the privilege of being the first physician of the New World to travel with the fleet that accompanied Columbus on his second voyage in 1493. The Royal Academy of History has preserved the Relación, which was written in 1494 to the council of Seville, describing the fauna and flora of the island of the Hispaniola. "The country is very remarkable... some dogs of various colours, as inour own country, but in shape like large house-dogs" noting they are dogs which don't bark. He also describes the Jutia "animal of colour, size and fur, like a little new-born rabbit, with long tails, and feet and hands like those of a rat; these animals climb up the trees"; snakes, and lizards, one of them probably a iguana (or jiguana) "an enormous kind of lizard was plump as a calf, with a tail as long as a lance". Of an infinite number of birds, which are reminiscent of the ducks and geese in our own country, the two that are domestic have been named by the chronicler as Zuruquia- or Sibuqueira- and Guanana, a kind of North American goose wintering in the Caribbean. The Hakluyt Society, of which Charles Darwin was board member at the time, translated the letter from Alvarez Chanca, together with other documents from the voyages of Columbus (Major, 1847) (pp. 40-42). It described the pain produced by the spice of the Manzanillo fruit (Hippomane mancinella) as well as its remedy "There were wild fruits from different woods, of which some were not very wisely tested, and a taste from only touching them with the tongue made faces swell with such great burn and pain that the faces seemed raging, they were cured only with cold things (Colmeiro, 1892) (p. (p.19). The manzanillo contains phorbol esters, which are cytokines. Why did they use plants with toxins capable of producing chemical irritation, severe poisoning or blindness? As the columnist describes it, what he saw was not an isolated observation. Did the Indians only use the plant as a poison on the tips of their arrows? The spicy fruits discovered in America proved to have clinical utility known to the indigenous people. Perhaps they also sought it's potential use as a treatment for chronic pain and other conditions? Recent studies have shown that hot peppers contain capsaicin which has wide therapeutic utility (Campbell, 1993). Prolonged exposure to capsaicin desensitizes the nociceptive terminals, allowing it to be used as an analgesic agent in the treatment of painful disorders (Caterina, 1997). The coca, which grows from Central America through to Peru, also has a local anesthetic effect which was known to the Incas. Chewing the coca leaf with alkaline produces kunka sukunka, which means "throat numb" in Quechan. The anesthetic effects of coca to treat toothache were described by Cobo in 1653 (Calatayud, 2003). We should also include in this paragraph the information contained in the letters of Christopher Columbus (Major, 1847) or in 'The Decades' of Peter Martyr (Lasso de la Vega and Cortez, 1988).

\section{The first descriptions}

The first Columbian texts were not written with scientific intent, with an exception for the Relación by Alvarez Chanca (Lopez-Piñero 1995). At this stage, what López Piñero considered as the "first reports", followed on from the "first descriptions" that begin with the Summary of Natural History of the Indies (Fernandez de Oviedo, 1526/1942). Gonzalo Fernandez de Oviedo y Valdes (14781557) made five trips to America, the first being in 1513. He was appointed Chronicler of the Indies in 1532. Upon returning from his fourth stay in America he published a much more detailed work than the Summary in Seville, being inspired to organize his work in the classic works of Pliny. In his General and Natural History of the Indies, Islands and Mainland of the Ocean Sea, he deals firstly with plants and then animals, starting with land, water, air and concluding with insects (Fernandez de Oviedo, 1535 1959). (Fernandez de Oviedo, 1535/1959). Separate consideration is deserved for his ideas about the indigenous people, whom he saw as homunculi suffering from incurable ailments. He wrote that they are "... naturally lazy and vicious, melancholic, cowardly, and generally deceitful and lazy people ... Idolatrous, libidinous, sodomites ... “ (Hanke, 1967) p. 34). These ideas led him to clash with the Dominican friar 'Bartolomé de las Casas' who considered the Indians equal and with the same rights as Spanish citizens. López Piñero (p.34) highlights that the lack of academic education favors the spontaneity of the descriptions. In fact, this is unlike what Peter Martyr of Angleria had written in his Decades (1493-1525) "as he spoke of what he had not seen ... his Decades seemed very flawed," Fernandez de Oviedo sought the observation of the direct report to be "faithfully ... informed". He illustrated his descriptions with xilograbados which enrich the work. The work of Pedro Cieza de Leon is also a result of personal experience (c1518-c.1560) Part one of the chronical of Peru, from (Cieza de Leon, 1553/1986), with abundant descriptions of the topography, climate, fauna and flora of the region. In 1883, the Hakluyt Society translated into English the second part of the chronicle and the journeys included in the first part (Cieza de Leon, 1883).

Friar Bernardino de Sahagun began compiling data for his General History of the Things of New Spain in 1540. The manuscript written in twelve books and two volumes was copied into different codices but was never brought to print during his lifetime. In the eleventh book, the first five chapters deal with the properties of animals, birds, fish and describe more than 250 animals, describing their appearance and how they live and behave (Sahagun, 1830). 


\section{The first scientific studies}

The first scientific studies, or third stage, had already taken place by the last third of the sixteenth century. Here we must mention Monardes Nicolas and Francisco Hernandez, both authors of solid education. In the seventeenth century these works of scientific nature are continued by the Jesuits José de Acosta and Bernabé Cobo. Monardes, without moving from Sevilla, published in three parts during 1565 and 1574 his Medical History of the things that are brought to our West Indies (Lasso de la Vega and Cortez, 1988). The work of Francisco Hernandez is much more ambitious since it has the support of Philip II. From 1570 to 1577 Francisco Hernandez, who is "the general chief physician of our Indies", lead the first scientific expedition to the New World visiting all the territories of New Spain, and performing some outstanding work. Three centuries later Humboldt tells us that (1855, pp. 333-334) "Hernandez, physician to Philip II, was sent by the monarch to Mexico, to reproduce all the vegetable and zoological curiosities of the country in wonderful drawings. He was able to enrich their collections by making copies of many paintings that depicted objects of natural history, that had been made with extraordinary detail by order of a king of Tezcouco, Nezahoualcoyotl, half a century before the arrival of the Spanish". He also made drawings from the collection of medicinal plants from the Houaxtepec garden next to a Spanish built hospital and fossils of mastodons called "bones of giants ... [and] ... they show the degree of imagination of the first interpretations made of this material". On his return he delivered to the King 38 volumes of texts, paintings and drawings, made by artists who accompanied him about the fauna, flora and minerals (Lopez-Piñero 1995). In 1578, a year after his return to Spain Francisco Hernandez died, and by a letter from Count de Coruña sent to the King D. Philip II in 1581, we know that Dr. Juan de Vides was recommended for the medical board of New Spain given "the desirability of continuing the story that Francisco Hernandez had started (Development, 1877). Eighty years after, Philip IV commissioned the edition to Reccho (1651) but most of this costly edition was never published and the original was lost in a fire in the library of El Escorial, 1671. However, the work of Francisco Hernandez was known in Europe from some preserved copies which could be made into various editions (Alvarez Peláez R. Fernández González, 1998).

The Jesuit José de Acosta (1539-1600) arrived in America towards 1573, lived in Santo Domingo, Mexico and Peru, and in 1587 returned to Spain. His good relations with Philip II facilitated the publication of De Natura Novi Orbis in 1589. The following year his American studies appeared published as Natural and Moral history of the Indias (Acosta J. d., 1590/1792) which had a great impact at the time. Nowadays it remains being a work which provokes interest and re-edicions are continually published from the English version made by Edward Grimston in 1604, and edited in 1880 by Clements Markham for the Hakluyt Society (Acosta J., 1604/1880). He says "the own birds of the Indies, now are of diverse species, of the same as others here, there are remarkable birds in the Indies ... in Peru there are birds called Tominejos, so tiny that I often doubted if I was seeing them fly, or if they were bees or butterflies, which are actually more like birds. On the contrary, the birds called Condors, are of immense size, and so strong that not only can they open a sheep and eat it, but also a calf. The Avras Callers, otherwise known as Buzzards, I believe are a type of Raven: they have a strange swiftness and a no less strange sight (p. 274). With regards to chickens, which Darwin will later examine, he writes "I doubt if the Spanish had been in the Indies before going, because in relation to the discovery of the Solomon Islands it is said that they found chickens and pigs from Spain ... (p. 277 ). The armadillos are said to have "a multitude of shells, like armor that opens and closes as they want, unfolding as they want" (p. 278).

He says to have personally seen monkeys of the Indies with such skill that "it appears they have speech and reason: and when passing through the trees they seem to want to imitate the birds ...they wrap their tails around the branches, and throw themselves wherever they want and when space is so large that they cannot jump to the next branch, they have a strange skill of grabbing the tail of one another, which in turn makes a string of many tails: after all the waving, or swinging, the first monkey, helped by the strength of others, jumps, reaches and grasps the branch, and supports the others, until they arrive, as they say, one to the tail of another. The jokes, tricks and pranks that they make, are easy with such space: the skills that they achieve, when they use them, do not seem of brute animals, but of human understanding "(p. 279). He preferred to tell the personal observations, therefore, when listening to stories about the remarkable abilities of a monkey in the governor's house, he says, "it may be some exaggeration, that I didn't see it, more in fact I don't think there is an animal who so perceives and adapts itself to human conversation as this breed of monkeys. They have so many things, that I, seem not to give credit to fables, or because others do not have as such, I consider it best to leave this area "(p. 280). He describes more than thirty different species of animals and of the lazy, ironically named "sloth," he explains "Another charming animal, who for his excessive delay in moving is called a sloth, has three claws on each hand: shakes his feet and hands at a pace of extreme laziness: with a manner and facial features of a monkey: giving loud cries, passing through trees and eating ants "(p. 279).

Acosta felt the need to learn Quechua to complete his naturist education and to improve his work. He explains in the prologue that he had much difficulty giving reports of new things, trying to state the cause and reason for such novelties and oddities of nature in the West Indies, as it 
requires a good academic background. He had the same difficulty conducting discussions and investigations of the facts and history of the same ancient Indies and the natural inhabitants of the new world. Treating the facts and own history of the Indies-Acosta tells us-needed a lot of very intrinsic contact with the same Indians, of whom lacked most of what had been written about the Indies: either by not knowing their own language, or by not caring to know about their history: and so were content in relating some of their superficial things. Desiring then, to gain some more particular information about their things, I examined the practical and well versed men in such matters, and from their conversations and copious relationships I was able to take from them what I considered sufficient to give account of the habits and behaviour of these people. Humboldt highly valued the views about the form of land and people of America, saying that "the foundation of what today is called the Physics of the globe, regardless of mathematical considerations, is contained in the work of the Jesuit Jose de Acosta, entitled: Natural and Moral History of the Indies, as well as that of Gonzalo Hernandez de Oviedo, which appeared twenty years after the death of Columbus. Since the foundation of the societies, in no other era had it expanded so suddenly and in such a wonderful way, the circle of ideas which touch on the outside world and the relations of space. Never had it been felt so strongly the need to observe nature at different latitudes and at different levels of height from sea level, or to multiply the ways with whose help can force to reveal its secrets "(Humboldt A., 1855, pp. 315).

The Jesuit Bernabé Cobo (1580-1657) also wrote another Natural History of the New World that he finished in 1653 and may have had more influence if it had been published at the time. He came to the island of Santo Domingo in 1596 and stayed in America for 57 years touring the West Indies, Mexico and Peru, where he learned Quechuan to communicate better with the Indians and improve the documentation of his work. He spent forty years composing his work which he left handwritten, and of which only ten of the forty-three manuscripts have been found. The remaining missing books may have been lost or never actually written. The original work consisted of three parts: the first composed of 14 books. This first part takes account of "the nature and qualities of the New World with all the things of his farming and produce". Fortunately, in the ten books that have been preserved, is the story of plants and animals, where more than 250 animals of the American fauna are described. "The last four books of that first part are devoted to exposing the nature, condition and customs of the Indians, notably the Peruvians. The second part consisted of 15 books and the third part of 14. These two parts were intended to explain the political geography of the America and the History of the Discovery and subsequent vicissitudes of those territories and their inhabitants, both from the natives of Spain, as from the
Indigenous". (Cavanilles and Centi, 1917, pp. Note 20). The scrolls found in 1870 in the Columbian Library in Seville were published in four volumes by the Society of Bibliophiles Andaluces (Cobo, 1653/1890), (Cobo, 1653/1891) (Cobo, 1653 / 1892), (Cobo, 1653 / 1893). His other book, part of the History of the New World which he made into a separate manuscript in 1639 , was printed in 1882 before the main manuscript as History of the founding of Lima (Cobo, 1638/1882).

Cobo was the first author who described in writing the analgesic effect produced by chewing the coca leaf: "This happened to me, once when calling at a barber's to take out my tooth because it had been aching and hurt so much, the barber told me it was a shame to take it out, because it was in good health, and as a religious friend of mine turned up, he advised me to chew coca for a few days. I did so, which removed the toothache and the molar was fixed like the others ".(Cobo, 1653/1890, pp. 473-7).

The discovery of fossil remains, such as those which Darwin will later find, is described with amazement as they are "of such deformed enormity, that knowingly they were giants, and inter alia some primary bones of more than four feet long. Many other bones of the same proportion have been found elsewhere ... all were pieces, that had not been whole bone more than some molar teeth, but their unusually large size indicated they were from deformed bodies. The teeth were no less than a fist each; one was weighed at eleven ounces ... it was a molar, and was of the enormity that I have said; while it is true, that although it had a very perfect form of a molar, as a result of much ageing it looked more like a stone than a bone. "(Cobo, 1653 / 1892, pp. 110-111). In confirmation of the existence of giants, he continues saying, it is "the relic of some ruined buildings that we see in this kingdom, of huge and well cut stones".

\section{The expeditions of the nineteenth century}

The American expeditions, within this naturalist tradition, continued throughout the next two centuries, and among the names that stand out one should mention here those of Felix de Azara and the Baron von Humboldt. The natural history observations of Felix de Azara were continued by those of Buffon. The Baron Alexander von Humboldt also studied American fauna and flora (Humboldt, 1915) being the Marquis Mariano Luis of Urquijo the patron and protector of the expedition. Charles Darwin developed the theory of evolution taking into account the remarkable development of natural history that begins with the works of the Spanish from the discovery and what they had reported throughout the Old World. The main merit of the theory is that it can unify the sciences of life, proclaiming the existence of a biological continuity between human beings and making it possible to understand the relationships between structure and function (Darwin C., 1871, pp. 35). In his research he was able to 
appreciate from the outset that animal behavior was a very important factor to consider when identifying a species. He delved further into his work by analysing aspects of motor functions or aspects of perception. He didn't hesitate to analyse the role played by emotional expression, steering his ideas towards the development of the emerging scientific psychology promoted by functionalism and positivism. Darwin studied Comparative Zoology with Robert Grant at the University of Edinburgh in 1825. With little interest in medicine, he was interested in becoming a pastor of the Anglican Church, for which it was necessary to be B.A. graduate. For that reason in 1827 he applied for a place at Christ's College, Cambridge. There were extensive studies of Botany with John S. Henslow, of Geology with Adam Sedgwick, of Astronomy with Sir John Herschel and of Geology with Charles Lyell. It was 1831 when he obtained a B.A. degree and Henslow encouraged him to travel as a naturalist on the HMS Beagle scientific expedition accompanying Commander Robert FitzRoy. He was young and knew the success of Humboldt's expedition to equatorial regions of the New World. It is also possible that he already had news of the popular book of Azara (1809) Voyages dans l'Amérique méridionale who appears in The Variation of Animals and Plants under Domestication (Darwin C., 1868).

He embarked on an adventure that lasted five years, taking him around the world and changing his way of understanding the origin of the different species. During his trip he had several experiences that changed his way of understanding the reasons for the differences between very similar species in different territories. The existence of some variability between species was accepted in some circles, but was explained by admitting various creationist focuses instead of one single focus. A fact that interested him during his stay in Brazil was the treatment of the slaves. He thought that evolutionism fought the idea that races had been created separately. All races could have a common ancestor. This idea could be extended to the entire animal kingdom (Desmond, 2009). On his return to England he was busy organising and analysing the abundant observations made along the journey which he published in various editions. These formed the foundations to put forward his theory on the origin of species (C. Darwin, 1859). Darwin appreciated from the outset of his research that animal behavior was a very important factor to consider when identifying a species. Thus he said of the Caracara Carrion bird (Hawk scavenger) that it has a "connection between habits and structure that resemble the true hawks" (Keynes, 2000, pp. P xxiii). The behavioral observations made by Darwin aboard the Beagle have recently been analysed (Pérez et al, 2007). The work is limited to the findings that appear on the Journey of a Naturalist published in 1840 and the Voyage of the Beagle which appeared in 1845 . There were different editions, with a different number of chapters (21 chapters in an edition of 1845 or 23 in other editions of the same year) but essentially the data should be very similar. Darwin conducted some form of behavioral observation of 97 different animal species by making 157 references to patterns of behavior. For example, the bird "Tapaculo" (Ptoroptochos albículis):" The farmers tell us that it changes it's song 5 times a year, according to the seasons, I think it will, "of the puma" ensure that when a puma has been discovered and followed by such vigilance of its prey, it completely loses such practice forever". Darwin's interest in behavior was not an isolated occurrence nor a result of casual observations, but indicated a long-term prolonged interest for the study of behavior. Pérez describes six levels of observation and quantifies their proportions over the total work. During the journey he took notes: 1) consisting of the naming of the animal (28\%); example, "occasionally when one hears the plaintive cry of a potato bun-white flies (Myiobius albiceps) that is hidden in the cup of the trees "and 2) description (51\%); example: the Diodon antennatus, has the power to swell:" If it is taken out of the water for a few moments, when returned to the water it absorbs a huge amount of water and air through the mouth and gills. It absorbs this water and the air by two different media". 3) Simple experiments that would necessarily require field observation (3\%) Darwin wondered if, as Audubon supposed, vultures have a poor sense of smell and describes the test that he conducted "in the garden I did the following test: I wrapped a piece of meat in white paper passing in front of them ... I left the package a yard from an old male, I examined it very carefully for a moment and looked away without reverting. He moved closer to it each time, until he touched it with his beak, in an instant he tore the paper with his pecks".

It was after finishing the trip when he analysed and prepared his data for establishing the other three levels: 4) Comparisons (11\%), for example, linking anatomical structure and function: "there are several species of a family that by their conformation and habits are very close to our Starling: one of these species (Molothrus niger) several of these birds can often be seen perched on the back of a horse or cow ... this bird lays its eggs in the nests of others, as does the cuckoo", 5) Explanations (5\%) as references to why "an octopus changes color, you see that they are grey with yellow spots ... vesicles with fluid of various colors that expand and contract" and 6) Hypothesis ( 2\%), for example on the "food of the fox, the only animal in that area ... I guess that it feeds on small rodents living in quantity in the desert places". He also hypothesised about the fossils he found. For example in the Fossil of Toxodon he observed that it had "the size of a megatherium, but the teeth like that of rodents, and by the eyes and ears it would have aquatic behaviors like the manatee" (Pérez et al. 2007).

It is undisputed that the works realised by the Spanish during three centuries in America contributed significantly to the study of natural history in the Old World. Did the Spanish 
authors have any influence on Darwin? If we focus on Felix de Azara, the author closest to Darwin in time, we find that in the Origin of Species, Humboldt is mentioned 16 times. Second place is shared by Azara together with Henslow, each appearing 10 times. If we consider all of Darwin's works that appears in English in new editions or translations until the time of his death, then the total number of citations that can be found on Darwin Online is 419 (van Wyhe, 2002-8). Acosta appears in two books, one citing the magnitude of the tsunami of 1586 (Darwin CR, 1846) p.65. Indeed Acosta (1604/1880) had described it thus: "The sea also made the same move then as it did in Chile, which was shortly after the earthquake, leaving the beaches very turbulent and entering inland nearly two miles, because it rose more than fourteen fathoms up, and covered all of that beach, swimming in the water was said to be the beams and wood that had been there". (p. 178).

The other book explains that domesticated poultry, despite the great variability of races, all could have a common origin in a single species from the wild pheasant Gallus bankiva, common in India and Southeast Asia from which they all descend, compared to the proposal that multiple origins exist. "I know-he says-that an ancient author, Acosta, speaks of birds of poultry already inhabited in America at the time of discovery" (Darwin C., 1868, pp. 252). Acosta makes this reference to emphasise the evidence that preserved the Indigenous name "of domestic birds I have marveled at the chickens, because indeed the Spanish had them before going; and its clear sign of taking names from them, that they call the goose Gualpa, and egg Toronto, and the same refrain that we call a man a chicken to perceive him a coward, is the same used by the Indians "(p. 271). There are animals that were already in the Indies and he wondered how they could have arrived there. Undoubtedly, others were brought by the conquerors "they were not there when the Indies were discovered, not yet there one hundred years: and besides being business that still has living witnesses, is enough proof to see, that the Indians did not have in their language their own words for these animals, but made use of the same Spanish words, athough corrupt, because from where the thing came to them, as they could not know, they took the Spanish word. This rule I have found useful to determine what things the Indians had before the Spanish came, and what things they didn't. For those that they already had and knew, they also gave them their name: when they received new names they gave them the new names, which are originally the same as the Spanish, but pronounced in their own way, like the horse, wine and wheat, \&c. They were found, therefore, to be animals of the same species as in Europe, without having been taken from Spanish "(p. 268). Cieza is also quoted, not directly by Darwin, but in the appendix of FitzRoy (1839) p.117). Finally, Francisco Hernandez is quoted by Darwin in two handwritten notes that are preserved from his voyage on the Beagle. There is a tab where it refers to the work Historia
Novae Hispaniae (sic) (Darwin C., 2002-8). The other note reports: "Dasypus peba, probably found in Mexico. It is a species with a very wide variety. Hernandez refers to it "(Darwin C., 2002-8). This animal is that which Hernandez called "the rabbit Ayotochtli cucurbitina otherwise known as tatou o armadillo". It is drawn in its two states-normal and curled-and is noted as a "monstrous animal ... defended on all sides by a crust-like covering war horses, consisting of layers together and moving, with which it surrounds and completely covers itself when needed, because of this the Spanish call it the armadillo, like someone said armored or armed "(Hernandez, 1959, pp. 296).

\section{Comparative psychology}

After publishing his books on the origin of species and the origin of man and those dealing with orchids, climbing plants and the domestication, Darwin published The Expression of the Emotions in Man and Animals (Darwin C., 1872). The importance of this work for psychology is its proposition of a biological continuity between man and animals, not only in anatomical but also functional aspects. The book lays the foundation for the development of comparative psychology to establish the relationship between emotional states of different species, including humans. (Boakes, 1984, pp. 206). The theory of Darwinian evolution faces issues related to geology, botany and biology; within biology it focuses on the relationship between structure and function in the motor, perceptive and expressive-emotional aspects. It is safe to say that the development of anatomy and comparative psychology studies driven by the works of Darwin and Romanes, bases itself on influences from the work and observations of those early Spanish explorers and researchers. The comparison of different species and questions about their origin, facilitated the transition from descriptive zoology to the scientific bestiaries. Many chroniclers wondered how those species had arrived there that had never been seen in the Old World, and if they had done so by land or sea "it was the big mammal fossils from the pampas and fauna from the American islands which suggested to Darwin the idea of transformism. Well to quote the authoritative opinion of Casey A. Wood, who attributed the birth of comparative anatomy to the knowledge of new species (Rey Pastor, 1951, pp. 136).

Darwin left to his friend and colleague George Romanes the completion of the comparative study of the role of evolution in the development of intelligence in Animal Intelligence (Romanes, Animal Intelligence, 1882) and of the mental processes in Mental evolution in animals (Romanes, 1883 ). The book cover tells us that it contains a posthumous experiment by Darwin (1883) on instinct, that would have been eliminated from The Origin of Species to condense the book. Was it really a matter of space that led Darwin to remove the 30 pages devoted to 
instinct from an already voluminous book? Perhaps, but the question remains, why remove these pages and not the others? Why did Darwin prefer to deal estensively with the study of emotions in a book? Despite the obvious interest, the study of animal intelligence and instinct was not addressed as a proper subject of a book. Is this perhaps why the study of these processes do not yet have the tools and adequate experimental studies, unlike what occurred with the emotions? Some descriptions in the book of Romans remarkably resemble those made centuries ago by the Spanish. With them began the comparison between different species of the New and Old World and it was they who questioned the intelligence and mental powers of the different animal species. However, despite its undoubted interest it was soon discredited in the scientific community. The same thing happened to the work of McDougall who saw that Darwin's successors had put too much emphasis on understanding the intellectual abilities of animals, while neglecting the most important contribution referring to the role of emotional states. For McDougall (1908) to understand the human emotion was to reach the sources of behavior and this led him to address the question of instinct proposing a psychology strongly based on heredity. For this, a decade later McDougall became the target of the attacks from the behaviorist circles.

Today, as more than a century has passed we can more clearly understand the meaning of some of the ideas expressed in those texts and other much earlier works. No doubt the pioneering work of Spanish naturalists facilitated the transition from descriptive zoology bestiaries to zoology science in all fields, including they behavior and the skills that comparative psychology have later studied. Beyond instinct, beyond learning and intellectual skills is the ability to feel. It makes no sense to say that man has more instincts than any other animal, but it is easier to make comparisons between species when thinking about of the attainment of emotional consciousness. As "there is no classification of the mental powers that are universally accepted" their observations are organsied in the most appropriate way in addressing their purpose to compare "the mental powers of man and lower animals." For Darwin (1871, pp. 3536) "there is no fundamental difference between man and the higher mammals in their mental faculties ... and with respect to animals of the lowest levels of the scale ... their mental powers are greater than expected. The variability of potential between individuals of the same species is an important point for us". Contemporary research has shown the nature of emotion and compassion, coining the term "emotional consciousness" (Dalai Lama, 2008). It is significant, for example, to what extent we can feel empathy when we see other fellows experiencing pain. Recent studies have shown that when we empathise with the pain of another person we do so using the same brain areas that are activated when we experience pain ourselves. The empathy caused by the pain mirrors is an emotional suffering, but not the sensory experience of physical harm, in the same brain areas (Singer, 2004) (Preston, 2002). It is possible that this result may be due to the activity of socalled mirror neurons which transform specific sensory information into motor information (Fabbri-Destro, 2008) and perhaps also emotional.

Experimentally it has been shown that hungry rhesus monkeys when they obtain food, by applying a "shock" to another monkey, they are able to delay gratification for days to prevent their fellow monkey receiving another shock (Masserman, 1964). Although there is always some delay this effect is more apparent when the recipient of the shock is someone familiar, rather than a stranger or a member of another species. De Waal (2006) argues in Primates and Philosophers that human morality has evolved from a continuum with animal sociability (Bekoff, 2007, pp. 86). Although this idea may seem novel, in fact Darwin (1871), following the Theory of Moral Sentiments by Adam Smith, had asked about the origin of the compassionate actions: "To see someone hungry, cold or fatigue reawakens such states in ourselves and to think of them is only painful. Then we are impelled to relieve the suffering of others to also relieve our own feelings. Similarly we revel in the pleasures of others ... sympathy is excited, to a remarkably higher degree, for a loved one more than for someone indifferent ( $p$. 106) ... ... the affection towards the lower animals seems to be one of the recent moral acquisitions ... (p.123) It is only an artificial barrier that prevents the affection extending to all men of all nations and races ... (p.122). To commemorate the bicentenary of the birth of Darwin also supposes a challenge that goes beyond mere scientific work of a naturalist: Could knowledge help us break those barriers?

\section{Referencias}

Acosta, J. D. (1590/1792). Historia natural y moral de las Indias, Vol. 2. Madrid: Pantaleón Aznar.

Acosta, J. (1604/1880). The natural \& moral history of the Indias. Vol. 2. London: Hakluyt Society.

Álvarez Peláez R., \& Fernández González, F. (1998). De materia medica Novae Hispaniae libri quatuor. Cuatro libros sobre la materia médica de Nueva España: el manuscrito de Recchi. Vol. 2. Valladolid y Aranjuez: Doce Calles.

Azara, F. D. (1809). Voyages dans l'Amérique Méridionale, Vol.4. París : Dentu Imprimeur Libraire.

Bandres, J., Campos, J. J., \& Llavona,R. (1989). Behavioral observation in America - The Spanish pioneers in the 16th and 17th Centuries. Bulletin of the Psychonomic Society, 27, 184-187.

Bekoff, M. G. (2007). The emotional lives of animals: A leading scientist explores animal joy, sorrow, and empathy - and why they matter. Novato, CA: New World Library.

Boakes, R. (1984). From Darwin to behaviourism. Pychology and the minds of animals. Cambridge, MA: Cambridge University Press. 
Borges, J. G. (1957). Manual de Zoología Fantástica. Mexico: Fondo de Cultura Económica.

Calatayud, J. G. (2003). History of the development and evolution of local anesthesia since the coca leaf. Anesthesiology, 98,1503-1508.

Campbell, E. B. (1993). Clinical applications of capsaicin and its analogues. In E. J. Wood, Capsaicin in the study of pain (pp. 255-272). London: Academic.

Campos, J. J., Montoya, P. J., \& Birbaumer, N. (2009). La observación naturalista en el mundo hispánico y su contribución al desarrollo de la Psicología Comparada. Revista de Historia de la Psicología, 30, 2-3, 57-64.

Caterina, M. S. (1997). The capsaicin receptor: a heat-activated ion channel in the pain pathway. Nature, 389, 816-824.

Cavanilles y Centi, A. L. (1917). Dos noticias historicas del inmortal botánico y sacerdote hispano-valentino Don Antonio Jose Cavanilles [Texto impreso] / por D. Antonio Cavanilles y Centi y D. Mariano Lagasca. Con anotaciones... por el Dr. Eduardo Reyes Prósper. Madrid: Artes Graficas Matheu.

Cieza de León, P. (1553/1986). Crónica del Perú . Madrid: Sarpe.

Cieza de Leon, P. (1883 a). The travels of Pedro de Cieza de León, AD 1532-50, contained in the first part of his chronicle of Peru, translated by C. R. Markham. London: Hakluyt Society.

Cobo, B. (1638/1882). Historia de la fundación de Lima. En Colección historiadores del Perú, M. Gonzalez de la Rosa, Vol. 1. Lima: Imprenta Liberal.

Cobo, B. (1653/1890). Historia del Nuevo Mundo por el P. Bernabé Cobo, de la Compañía de Jesús, publicada por primera vez con notas y otras ilustraciones de D. Marcos Jiménez de la Espada, Tomo 1. Sevilla: E. Rasco.

Cobo, B. (1653/1891). Historia del Nuevo Mundo por el P. Bernabé Cobo, de la Compañía de Jesús, publicada por primera vez con notas y otras ilustraciones de D. Marcos Jiménez de la Espada, Tomo 2. Sevilla: E. Rasco.

Cobo, B. (1653/ 1892). Historia del Nuevo Mundo por el P. Bernabé Cobo, de la Compañia de Jesús, publicada por primera vez con notas y otras ilustraciones de D. Marcos Jiménez de la Espada, Tomo 3 . Sevilla: E. Rasco.

Cobo, B. (1653/1893). Historia del Nuevo Mundo por el P. Bernabé Cobo, de la Compañia de Jesús, publicada por primera vez con notas y otras ilustraciones de D. Marcos Jiménez de la Espada, Tomo 4 . Sevilla: E. Rasco.

Colmeiro, M. (1892). Primeras noticias acerca de la vegetación americana. Madrid: Rivadeneyra.

Dalai Lama, E. (2008). Emotional awareness. New York: Henry Holt.

Darwin, C. (1845). Journal of researches into the natural history and geology of the countries visited during the voyage of H.M.S. Beagle round the world under the Command of Capt. Fitz Roy (2nd ed.). London: John Murray.

Darwin, C. (1846). Geological observations on South America. Being the third part of the geology of the voyage of the Beagle, under the command of Capt. FitzRoy, R.N. during the years 1832 to 1836. London: Smith Elder and Co.
Darwin, C. (1859). On the origin of species by means of natural selection, or the preservation of favoured races in the struggle for life. ( $1^{\text {st }}$ edition). London: John Murray.

Darwin, C. (1868). The variation of animals and plants under domestication. ( $1^{\text {st }}$ edition) Vol. 1. London: John Murray.

Darwin, C. (1871). The descent of man, and selection in relation to sex. ( $1^{\text {st }}$ edition) Vol. 1. London: John Murray.

Darwin, C. (1872). The expression of the emotions in man and animals. London: John Murray.

Darwin, C. (1883). A posthumous essay on instinct. In G. J. Romanes, Mental evolution in animals. With a posthumous essay on instinct by Charles Darwin. (pp. 354-384). London: Kegan Paul Trench \& Co.

Darwin, C. (2002-8). Hernandez F, (rough notes on ranges of animals) [Beagle animal notes]. In V. Wyhe, The Complete Work of Charles Darwin Online (CUL-DAR29.1.A34-A35). Retrieved from: http://darwin-online.org.uk/.

Darwin, C. (2002-8). Hernandez F, Historia Novae Hispaniae' [Beagle animal notes]. In V. Wyhe, The Complete Work of Charles Darwin Online (págs. CUL-DAR29.1.A33). Retrieved from: http://darwin-online.org.uk/.

de Waal, F. (2006). Primates and philosophers. Princeton, NJ: Princeton University Press.

Desmond, A. Y. (2009). Darwin's sacred cause: Race, slavery and the quest for human origins. London: Allen Lane.

Fabbri-Destro, M. F.-D. (2008). Mirror neurons and mirror systems in monkeys and humans. Physiology, 23, 171-179.

Fernández de Oviedo, G. (1535/1959). Historia general y natural de las Indias, islas y tierra firme del Mar Océano. (Colección Biblioteca de Autores Españoles, pp. 117-121),Vol. 5. Madrid: Atlas,

Fernandez de Oviedo, G. (1526/1942). Sumario de historia natural de las Indias. Madrid: Summa.

FitzRoy, R. (1839). Appendix to Volume II. En C. Darwin, Narrative of the surveying voyages of his Majesty's ships adventure and Beagle between the years 1826 and 1836, describing their examination of the southern shores of South America, and the Beagle's circumnavigation of the globe. London: Henry Colburn.

Fomento, M. D. (1877). Cartas de Indias / publicalas por primera vez el Ministerio de Fomento. Madrid: Manuel G. Hernández.

Hanke, L. (1967). La lucha española por la justicia en la conquista de América.(2 edición). Madrid: Aguilar.

Hernandez, F. (1959). Obras Completas: Tomo 3, Vol. 2. Historia Natural de Nueva España. Mexico, D.F.: Universidad Nacional de Mexico.

Hernandez, F. (1976). Obras Completas: Tomo 5, Vol. 2. Historia Natural de Cayo Plinio Segundo. Mexico, D.F.: Universidad Nacional de Mexico.

Humboldt, A. (1855). Cosmos: Essai d'une description physique du monde.Tomo II. Traduit par Ch. Galusky. Paris: Gide et J. Baudry.

Humboldt, A. V. (1915). Personal narrative of travels to the equinoctial regions of the New Continent, during the years 1799-1804. London: George Bell \& Sons. 
Keniston, H. (1920). List of works for the study of HispanicAmerican History, The Hispanic Society of America. New York, NY: The Cayuga Press.

Keynes, R. E. (2000). Charles Darwin's zoology notes \& specimen lists from H.M.S. Beagle. Cambridge, MA: Cambridge University Press.

Lasso de la Vega, \& Cortezo, J (1988). Biografía y estudio crítico de las obras del médico Nicolás Monardes. Sevilla: Padilla Libros.

Leon, C. D. (1883 b). The second part of the chronicle of Peru. Traducción C. R. Markham. London: Hakluyt Society.

Lopez-Piñero, J. (1995). Antonio de Ulloa y la tradición de la ciencia moderna en Sevilla. In M. V. Losada, Actas del II centenario de don Antonio de Ulloa (pp. 19-37). Sevilla: Escuela de Estudios Hispanoamericanos CSIC.

Lopez-Piñero, J. (1982). La ciencia en la historia Hispánica. Madrid: Salvat.

Major, R. (1847). Selected letters of Christopher Columbus with other original documents related to the four voyages to the New World. London: Hakluyt Society.

Masserman, J. W. (1964). Altruistic" behavior in rhesus monkeys. American Journal of Psychiatry, 121, 584-85.

McDougall, W. (1908). An introduction to social psychology. London: Methuen.
Pérez, A., Gutierrez, G. \& Segura, A. (2007). Observaciones conductuales en el viaje de Darwin a bordo del Beagle. Revista Latinoamericana de Psicología, 39(3), 503-521.

Preston, S. A. (2002). Empathy: its ultimate and proximate bases. Behavioral and Brain Sciences, 25, 1-20.

Recchi, N. (1651). Rervm medicarvm novae hispaniae thesavrvs sev plantarvm animalivm mineralivm mexicanorvm historia ex Francisci Hernandez. Roma: Vitalis Mascardi.

Rey Pastor, J. (1951). La ciencia y la técnica en el descubrimiento de América, (3th ed.). Buenos Aires: Espasa Calpe.

Romanes, G. (1882). Animal intelligence. London: Kegan Paul Trench \& Co.

Romanes, G. (1883). Mental evolution in animals. London: Kegan Paul Trench \& Co.

Sahagún, B. (1830). Historia general de las cosas de Nueva España. Mexico: Alejandro Valdés.

Singer, T. S. (2004). Empathy for pain involves the affective but not sensory components of pain. Science, 3, 1157-1162.

van Wyhe, J. (2002-8). The complete work of Charles Darwin online. Retrieved from http://darwin-online.org.uk/

Received September 21, 2010

Revision received January 04, 2011

Accepted February 10, 2011 